\title{
Nutrient and grazing influences on a subtropical seagrass community
}

\author{
Karen J. McGlathery* \\ Section of Ecology and Systematics, Division of Biological Sciences, Corson Hall, Cornell University, Ithaca, \\ New York 14853-2701, USA
}

\begin{abstract}
Nutrient and grazing levels were manipulated in a 10 wk field experiment at 2 sites in a subtropical lagoon in Bermuda to evaluate their relative effects on the abundance and growth of the dominant seagrass and macroalgae. One site was eutrophic, the other mesotrophic to oligotrophic. Nutrients were added to the sediment-water interface using slow-release fertilizer, and the dominant herbivores in the system, the purple sea urchin Lytechinus variegatus and herbivorous fishes (primarily the resident parrotfish Sparisoma radians), were partitioned using roofless cages. Nutrient enrichment caused an increase in the percent cover of the filamentous, mat-forming macroalga Spyridea hypnoides. This response is consistent with the dominance of this macroalga in the eutrophic portion of the bay and with previous work showing that this species has rapid nutrient uptake and growth potentials, enabling it to take advantage of elevated nutrient concentrations in the water column. Enrichment also caused a decline in both the percent cover and aboveground biomass of the dominant seagrass Thalassia testudinum at the eutrophic site but not at the mesotrophic site. Estimates of productivity and grazing losses during the experiment indicated that the decline was primarily a result of enhanced grazing by herbivorous fishes and not of either increased urchin grazing or reduced seagrass growth from shading. Nutrient enrichment caused an increase in the nitrogen content of the seagrass, particularly at the eutrophic site. Fertilization may have been less effective at the mesotrophic site due to the dilution of fertilizer nutrients in greater current flow. Herbivorous fishes preferentially chose the highnitrogen epiphyte-covered $T$ testudinum at both sites, but particularly selected the higher-nitrogen seagrass at the eutrophic site. Intense grazing on this nitrogen-enriched $T$ testudinum was responsible for the creation and maintenance of small-scale $\left(<1 \mathrm{~m}^{2}\right)$ patches in aboveground biomass in the seagrass meadow, an occurrence also observed naturally in places at the eutrophic site.
\end{abstract}

KEYWORDS: Seagrass $\cdot$ Thalassia $\cdot$ Macroalgae $\cdot$ Spyridea $\cdot$ Nutrients $\cdot$ Herbivory

\section{INTRODUCTION}

Resource availability and consumers both influence natural communities, although the relative importance of each is usually not well known (Hunter \& Price 1992, Power 1992). In marine systems, nutrient availability has been shown to affect species composition by altering the competitive advantage of some macroalgae, especially when enrichment (natural or anthropogenic) favors fast-growing opportunistic species (Borowitzka 1972, Murray \& Littler 1978, Gappa et al. 1990,

\footnotetext{
- Present address: Department of Freshwater Ecology, National Environmental Research Institute, Vejlsøvej 25, PO Box 314 DK-8600 Silkeborg, Denmark
}

Valiela et al. 1990, Wooton 1991). Selective grazing also can affect algal species composition in coral reef and rocky intertidal communities, as edible or undefended algae are replaced by inedible taxa when grazing intensity increases (Lubchenco \& Gaines 1981, Hay 1991). At times this consumption can be intense, creating temporary grazing patches in the algal community that vary in size and frequency of disturbance (Carpenter 1986). Nutrient availability and grazing can interact in a variety of ways to influence natural communities, but to date marine research has contributed little to the synthesis of the how such 'bottom-up' and 'top-down' forces are linked (Menge 1992). This may be due partly to a historical bias that nutrient and grazing effects operate on different spatial scales and 
partly to the greater logistical difficulties involved in conducting nutrient enrichment experiments in open marine systems compared to more closed freshwater and terrestrial habitats (Menge 1992).

Nearshore seagrass communities provide appropriate marine systems in which to evaluate the relative importance of nutrient and grazing effects, because the influence of these factors can be compared over similar spatial scales and also can be manipulated experimentally in the field. Many nearshore systems are impacted by nutrient enrichment from terrestrial sources, and distinct nutrient gradients often exist over a relatively small area (100s of meters) (Valiela et al. 1990, McGlathery 1992b). Eutrophic coastal waters are typically dominated by filamentous macroalgae (McComb et al. 1981, Fujita 1985, Virnstein \& Carbonara 1985, Valiela et al. 1990), and increased macroalgal biomass has been correlated with the loss of extensive seagrass meadows presumably because the dense macroalgal mats reduce light availability below that which is necessary to support seagrass growth (Valiela et al. 1990). In the tropics and subtropics, nutrient enrichment often affects shallow bays and coastal lagoons that have restricted circulation with offshore oligotrophic waters (von Bodungen et al. 1982). Grazers are abundant in these nearshore systems, and based on the size of their foraging ranges their impact should occur over the same spatial scale as nutrient enrichment effects (Thayer et al. 1984). Throughout the Caribbean and Bermuda, the dominant herbivores in these seagrass beds are commonly the purple sea urchin Lytechinus variegatus and several species of parrotfish of the genus Sparisoma (Lobel \& Ogden 1981, Thayer et al. 1984, Sterrer 1986). Thalassia testudinum is the preferred food source of $S$. radians which resides in nearshore seagrass meadows (Lobel \& Ogden 1981), and of several reef-dwelling Sparisoma spp. that feed in these seagrass beds primarily as juveniles (Randall 1967), L. variegatus is a more generalist herbivore, feeding on detritus and epiphytes as well as live seagrass blades (Vadas et al, 1982, Keller 1983).

Little is known of the interaction between nutrient enrichment and grazing in nearshore seagrass communities, but one would expect that if these factors are dynamically linked, consumer impact would vary according to nutrient availability. For example, herbivory should be higher if enhanced nutrient levels increase food quality and/or its availability (growth, abundance) (Menge 1992). This study was designed to evaluate the relative importance of these 2 factors for a seagrass community in a shallow subtropical lagoon where nutrient levels were known to vary with distance from terrestrial inputs. I did not attempt to follow every member of the community, but instead was primarily concerned with the influence of nutrients and herbivory on the distribution and abundance of the dominant macrophytes, the seagrass Thalassia testudinum and the filamentous macroalga Spyridea hypnoides (quantitative changes sensu Menge 1992). The specific objectives of the study were to test if: (1) nutrient availability was an important control on macrophyte species composition in the seagrass community, favoring filamentous macroalgae at high ambient nutrient concentrations; and (2) there was an interaction between resources and herbivory because selective grazing varied according to food quality. Macrophyte species abundance was first determined as a function of distance from the terrestrial nutrient sources (groundwater inputs and surface runoff); this pattern gave an indication of the long-term effect of nutrient enrichment. Nutrient and grazing levels were then manipulated in the field over a $10 \mathrm{wk}$ period at 2 locations within the bay that differed with respect to water column nutrient levels. Changes in species distribution, abundance and growth were used to assess the shorter-term response of the seagrass community to variations in nutrient availability and grazing pressure, and to their interaction.

\section{METHODS}

Study site and species. This study was conducted from June through September 1990 in Bailey's Bay, a shallow lagoon on the north shore of Bermuda $\left(32^{\circ} \mathrm{N}\right.$, $64^{\circ} \mathrm{W}$ ). The bay is approximately $2 \times 10^{4} \mathrm{~m}^{2}$ in area and is partially protected by small islands at its mouth (Fig. 1). Within the bay a nutrient gradient extended from the eutrophic inner bay to the lower nutrient (mesotrophic-oligotrophic) outer bay adjacent to the islands, presumably resulting from groundwater nutrient inputs (McGlathery 1992a, b). During 1989-1991 dissolved inorganic nitrogen (DIN) concentrations in the water column were typically 2 to $10 \times$ higher in the inner bay, but soluble reactive phosphorus (SRP) levels were low throughout the bay (McGlathery 1992a, b). Mixed-species seagrass beds, with associated macroalgae, were present at depths of 1 to $3 \mathrm{~m}$ throughout the bay, but were absent from its deeper (4 to $6 \mathrm{~m}$ ), dredged center. The light extinction coefficient $\left(k_{\mathrm{d}}\right)$ in the water column was slightly lower at the eutrophic site from enhanced phytoplankton growth $\left(k_{\mathrm{d}}=\right.$ $\left.0.28 \mathrm{~m}^{-1}\right)$ than at the mesotrophic site $\left(k_{\mathrm{d}}=0.34 \mathrm{~m}^{-1}\right)$. However, due to the shallow nature of the bay, light intensities were high throughout. The experimental plots in the inner bay were located at $2 \mathrm{~m}$ depth and received $57 \%$ of surface irradiation, as compared to $71 \%$ reaching the outer bay plots at $1 \mathrm{~m}$ depth.

The turtlegrass Thalassia testudinum was the dominant seagrass throughout the bay and occurred both in 


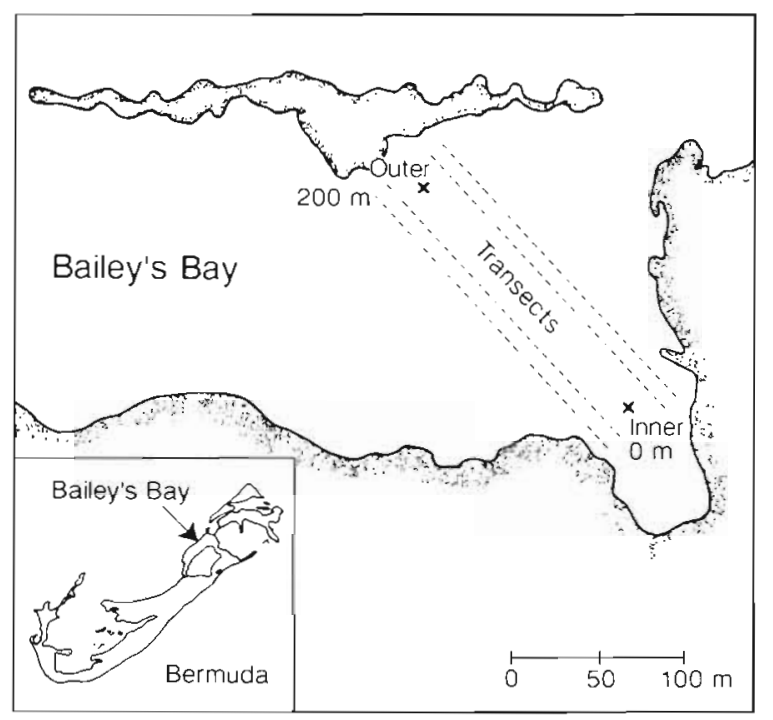

Fig. 1. Map of Bailey's Bay on Bermuda's north shore. The bay is approximately $2 \times 10^{4} \mathrm{~m}^{2}$ in area, with a $200 \mathrm{~m}$ nutrient gradient extending from the eutrophic inner bay to the mesotrophic outer bay adjacent to the islands. Macrophyte distribution was determined along 4 parallel transects from the shore $(0 \mathrm{~m})$ seaward $(200 \mathrm{~m})$. (x) Locations where biweekly water column samples were taken to characterize nutrient availability

dense monospecific stands and in mixed-species beds with the other tropical seagrasses Syringodium filiforme and Halodule wrightii. The seagrass meadows were patchy and were often separated by discrete bare areas created by local disturbances such as wave action from heavy storms and boat traffic. Localized patches created by grazing (typically covering an area of 0.25 to $1.0 \mathrm{~m}^{2}$ ) also occurred within the seagrass beds at the eutrophic site, but were absent from the mesotrophic site. Both calcareous and filamentous macroalgae were associated with the seagrasses. The calcareous, rhizophytic macroalgae included several species from the genera Halimeda and Penicillus (Chlorophyta) and occurred throughout the bay in low densities ( 0 to 24 individual thalli $\mathrm{m}^{-2}$ ), with no marked differences in distribution along the nutrient gradient (McGlathery 1992b). The dominant filamentous matforming macroalga was Spyridea hypnoides (Rhodophyta), a highly branched species which typically aggregated to form free-floating or attached mats over the bare substratum and seagrass beds and occurred only in the eutrophic part of the bay. This species has little nutrient storage capacity and must rely on ambient nutrient levels in the water column to meet its high growth demands (McGlathery 1992a).

The grazers in this system can be separated into 3 functional groups according to foraging characteristics. (1) Herbivorous fishes are mobile grazers with relatively large foraging ranges where the frequency of grazing in any one area is typically low (Thayer et al. 1984, Carpenter 1986). The resident parrotfish Sparisoma radians was the only herbivorous fish observed grazing on the seagrasses in Bailey's Bay, leaving conspicuous scallop-shaped bite marks on the Thalassia testudinum blades (Hay et al. 1983). However, since other Sparisoma spp. or the surgeonfish Ancanthurus sp. may also have foraged in the area during the study period, the discussion will refer generally to herbivorous fishes. (2) The echinoid Lytechinus variegatus is a generalist herbivore (Vadas et al. 1982, Keller 1983), which can influence seagrass biomass and distribution at high densities (20 to 40 ind. $\mathrm{m}^{-2}$; Valentine \& Heck 1991). (3) Mesograzers, namely crustaceans (amphipods) and small gastropods, graze in seagrass meadows, but their impact is restricted to epiphytes on the seagrass blades (Klumpp et al. 1992, Neckles et al. 1993, Williams \& Ruckelshaus 1993) and possibly to small algal filaments. Carpenter (1986) showed that grazing by these herbivores, even at high population densities when predators were absent, was of minor importance in coral reef macroalgal communities and only removed a small portion of daily algal production. Accordingly, this study focused on the impact of grazing by urchins and herbivorous fishes and did not attempt to control mesograzer abundances. Green turtle Chelonia mydas populations are severely depleted in Bermuda's waters (Sterrer 1986) and are unlikely to influence seagrass biomass in Bailey's Bay.

Nutrient gradient and macrophyte distribution. To establish the difference in nutrient levels between the inner and outer portions of the bay, water column nutrient concentrations were measured at approximately 2 wk intervals throughout the 4 mo study. Water column samples were taken in triplicate at both sites at $0.5 \mathrm{~m}$ above the sediment surface and within $1 \mathrm{~h}$ of low tide (Fig. 1). The samples were kept on ice in the dark while being transported to the laboratory, and then were immediately filtered through acid-washed $0.45 \mathrm{\mu m}$ Millipore filters. Analyses of ammonium and SRP concentrations were made on triplicate subsamples within $6 \mathrm{~h}$ of sample collection. Ammonium concentrations were determined using the indophenol blue method, modified from Strickland \& Parsons (1972). SRP was assayed following reaction with a molybdate-antimony reagent (Stainton et al. 1974). The remaining sample was frozen for later analysis of nitrite+nitrate (hereafter referred to as nitrate), which was determined after cadmium reduction on a Scientific Instruments AP-100 autoanalyzer following the method of Grasshoff et al. (1983).

The distributions of the dominant macrophytes, Thalassia testudinum and Spyridea hypnoides, were determined along the nutrient gradient within Bailey's Bay 
in July 1990 by surveying 4 parallel $200 \mathrm{~m}$ transects, extending from the eutrophic inner bay to the mesotrophic outer bay. Two transects were located $\sim 10 \mathrm{~m}$ apart on either side of the bay where the water depth ranged from 1 to $3 \mathrm{~m}$, thus avoiding the bay's deeper, dredged center (Fig. 1). At $20 \mathrm{~m}$ intervals along each transect, the percent cover of each macrophyte species was determined in a $0.25 \mathrm{~m}^{2}$ quadrat located at a random distance, within $5 \mathrm{~m}$, perpendicular to the transect line. The quadrat was subdivided into 100 cells, $5 \times$ $5 \mathrm{~cm}$, and the percent cover was determined by counting the number of cells occupied by each species. This method measures horizontal cover as frequency distribution, and is appropriate for comparing the relative densities of macrophytes with different morphologies. Thalassia testudinum was assigned occupancy to the cell in which the shoot base occurred.

Herbivore census. Average abundances of Lytechinus variegatus individuals were determined in July before the start of the field experiment. Individuals were counted in 10 haphazardly thrown $1 \mathrm{~m}^{2}$ quadrats in both the inner (defined as 0 to $40 \mathrm{~m}$ from the shore) and outer ( 160 to $200 \mathrm{~m}$ from the shore) parts of the bay. Herbivorous fishes were censused in September, during the experimental treatment period, by counting the number of individuals while swimming along each of 3 parallel $20 \mathrm{~m}$ transects at both sites (inner and outer bay) over a $5 \mathrm{~min}$ period.

Experimental design. In the field experiment, a $2 \times 2$ factorial design was used to separate the effects of urchin and herbivorous fish grazing and nutrient enrichment on the dominance of Thalassia testudinum versus Spyridea hypnoides in the macrophyte community (Fig. 2). At both the eutrophic and mesotrophic sites, 4 plots were randomly assigned to each of 4 treatments: (1) +nutrients, +urchins; (2) +nutrients, no urchins; (3) no nutrients, +urchins; and (4) no nutrients, no urchins. All treatment plots were surrounded by a $45 \mathrm{~cm}$ high, $1 \mathrm{~m}$ diameter roofless cage enclosing an area of $0.8 \mathrm{~m}^{2}$, which was constructed of $25 \mathrm{~mm}$ mesh plastic-coated garden fencing. The cages in this study were designed primarily to include or exclude urchins from the study plots, and because they had no tops, fish could move freely in and out of the cages in all treatments. In the urchin-exclusion treatment, herbivorous fishes were the dominant grazers. The plots were located at least $5 \mathrm{~m}$ apart in order to reduce any carryover effects from treatments of neighboring plots. The cages were made of a large-sized mesh so as to have a minimal impact on current flow and were scrubbed every 3 to $4 \mathrm{~d}$ to reduce algal fouling. One potential problem with caging treatments is that the structure of the cage may provide refuge for herbivores and concentrate or modify their activity. Foraging rates could be artificially high if fish were attracted to the cage structure, however no preference for the cages by herbivorous fishes was observed during the experiment. Direct evidence of a caging effect on grazing rates and macrophyte cover was also determined by comparing the caged control (no nutrients, no urchins) with unmanipulated control plots $(n=4)$ in the vicinity of the cages at each site. However, any cage effect should be the same among all treatments and should not account for treatment differences. The topless cages provided no protection from fish predators, and increases in mesograzer abundances were not observed in any of the treatments at either site.

Two Lytechinus variegatus were added to each of the +urchin plots for the grazing treatments, representing a density $\left(2.5 \mathrm{~m}^{-2}\right)$ which was slightly higher than that determined from repeated sampling in the field (Table 1). Since L. variegatus grazing rates are density dependent (Greenway 1976), care was taken to approximate the average field density in the urchin treatment with mature individuals (test diameter $>40 \mathrm{~mm}$ ). The cages were checked every $2 \mathrm{~d}$, and urchins were never observed to have climbed out of the cages. Urchin mortality from predation or aggression was rare, and any losses were immediately replaced. Keller (1983) noted that substantial mortality of $L$. variegatus in similar sized cages only occurred at densities $>16 \times$ natural abundances.

Nutrients were added to the +nutrient plots as ammonium sulfate and ammonium phosphate in a N:P ratio of 8:1 (molar) using slow-release fertilizer stakes (Jobe 'Tree Spikes', Lexington, KY, USA) (Williams

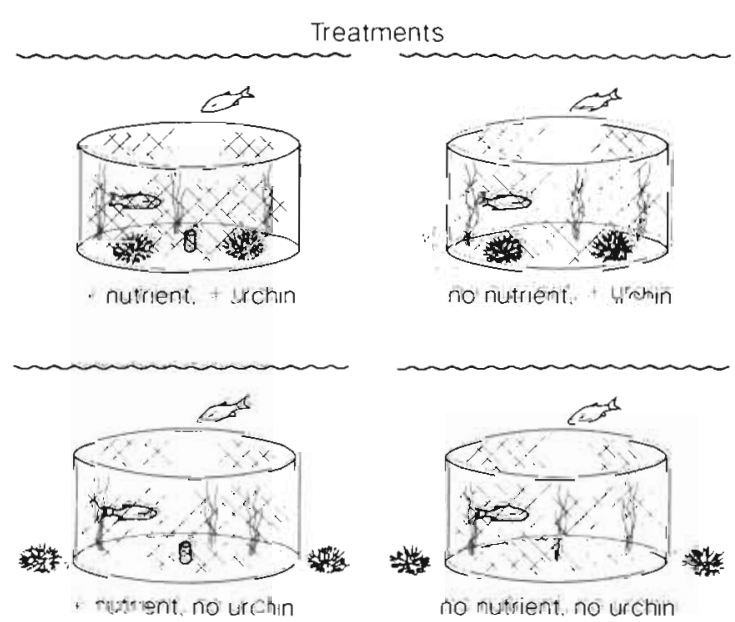

Fig 2. Nutrient enrichment and grazing treatments; nutrients were added as ammonium sulfate and ammonium phosphate using slow-release fertilizer stakes, and urchins were either included or excluded from the $45 \mathrm{~cm}$ high, $1 \mathrm{~m}$ diameter roofless cages. Fish could move freely throughout the treatments and were the dominant herbivores in the urchin exclosure treatments. Note that the size of the fish is slightly exaggerated in the drawing 
Table 1. Mean densities $( \pm 1 \mathrm{SE}$ ) of the dominant herbivores in Bailey's Bay, measured as no. $\mathrm{m}^{-2}$ for urchins $(\mathrm{n}=10$ ) and as no. $20 \mathrm{~m}^{-1}$ transect during 5 min visual census $(\mathrm{n}=3)$ for herbivorous fishes

\begin{tabular}{|lcc|}
\hline & $\begin{array}{c}\text { Eutrophic } \\
\text { inner bay }\end{array}$ & $\begin{array}{c}\text { Mesotrophic } \\
\text { outer bay }\end{array}$ \\
\hline $\begin{array}{l}\text { Urchin Lytechinus variegatus } \\
\text { No. } \mathrm{m}^{-2}\end{array}$ & $1.6(0.5)$ & $1.5(0.4)$ \\
Range & $0-5$ & $0-4$ \\
Parrotfish Sparisoma spp. & & \\
$\begin{array}{l}\text { No. 20 } \mathrm{m}^{-1} \text { transect } \\
\text { Range }\end{array}$ & $1.0(0.3)$ & $1.7(0.2)$ \\
& $0-1$ & $1-4$ \\
\hline
\end{tabular}

1990). The stakes were set with approximately a quarter of the length into the sediment so as to fertilize the sediment-water interface. One fertilizer stake was added per plot and supplied $59 \mathrm{~g} \mathrm{~N}$ and $15 \mathrm{~g} \mathrm{P} \mathrm{m}^{-2}$. Dissolution rates varied somewhat according to changes in current flow and wave action; fertilizer stakes typically lasted $2 \mathrm{wk}$, at which time they were replaced.

Changes in macrophyte distribution. The distributions of Thalassia testudinum and Spyridea hypnoides were determined from percent cover estimates made 3 times during the treatment period. In July 1990, the initial percent cover was measured as the number of cells occupied by each species in $0.25 \mathrm{~m}^{2}$ quadrats that were located in the center of each cage. At Weeks 6 and 10 of the treatment period, the quadrats were resurveyed and the change in percent cover was determined by comparing these values with the initial estimates.

Thalassia testudinum biomass and productivity. Because seagrasses grow basally from an extensive rhizomal system, percent cover was not the most sensitive measure of aboveground biomass. A seagrass shoot could be grazed to near the sediment surface, representing an extreme reduction in aboveground biomass, but would be counted in the frequency distribution measure. To quantify the change in aerial cover more accurately for $T$. testudinum, 8 shoots from each treatment plot and from the cageless controls were selected randomly and harvested at the end of the experiment $(10 \mathrm{wk})$. The leaf area $\left(\mathrm{cm}^{2}\right)$ for each shoot was determined using a Licor Model LI-3000 Leaf Area Meter. Aboveground biomass of $T$. testudinum was also determined for the 8 shoots harvested from each plot. Epiphytes were removed by manual scraping before the leaves were rinsed with deionized water and dried to a constant weight at $60^{\circ} \mathrm{C}$. The average dry weight per shoot was determined for each plot and then multiplied by the number of shoots per $0.25 \mathrm{~m}^{2}$ quadrat to estimate the aboveground biomass for that plot. Treatment averages $(n=4)$ were calculated per $\mathrm{m}^{2}$.
At the end of the experiment (Week 10), the rates of light-saturated photosynthesis $\left(P_{\max }\right)$ and respiration were compared for both nutrient-enriched and unenriched Thalassia testudinum. Differences between enrichment treatments would be expected if shading from macroalgae or epiphytes had a negative impact on net carbon balance of $T$. testudinum. Production and respiration rates were measured as changes in dissolved oxygen in a Clark-type oxygen electrode (Rank Bros.) during short (15 min) incubation periods. Sampling was standardized by using a $2 \mathrm{~cm}$ leaf segment cut from the base of the shoot; these sections represented new growth and were free of epiphytes. Each segment $(n=3)$ was placed in filtered $(0.22 \mu \mathrm{m})$ Sargasso seawater with rapid mixing; light was provided by a Kodak projector lamp at an irradiance known to saturate photosynthesis $\left(500 \mu \mathrm{E} \mathrm{m}^{-2} \mathrm{~s}^{-1}\right)$ for the $P_{\max }$ measurements, and respiration was measured in total darkness. The temperature was held constant during the incubations at $28^{\circ} \mathrm{C}$, which represented ambient field conditions. Photosynthesis and respiration rates are expressed as $\mu \mathrm{mol} \mathrm{O}_{2} \mathrm{dm}^{-2} \mathrm{~min}^{-1}$.

Relative growth rates of Thalassia testudinum for the +nutrient and no nutrient treatments were determined in September (Week 7), in part to estimate leaf biomass available to grazers. In each plot, 3 ungrazed shoots were marked at the shoot base with a needle hole, using as a reference point a $6^{\prime \prime}(\sim 15 \mathrm{~cm})$ PVC ring which was placed in the sediment around the seagrass shoot so that the top of the ring was level with the sediment surface. At the time of marking, the initial area of the shoot above the needle mark was determined. After $9 \mathrm{~d}$, the shoots were cut at the base using the same reference point; since seagrasses grow basally, all tissue between the scar tissue developed around the needle hole and the cut edge represented new growth (modified after Zieman 1974). The leaf tissue was scraped clean of epiphytes, rinsed with deionized water, and dried to a constant weight at $60^{\circ} \mathrm{C}$. The growth of the seagrasses was determined over the $9 \mathrm{~d}$ period as new tissue ( $g$ dry wt) $\mathrm{d}^{-1}$, normalized to the total shoot biomass (initial + new growth). To compare the relative growth rates for the +nutrient and no nutrient treatments, only shoots where the new growth had not been reduced by grazing were used.

Herbivorous fish grazing intensity. High grazing loss in the urchin exclosure treatments in the eutrophic inner bay suggested that fish grazing strongly impacted Thalassia testudinum aboveground biomass at this site. An adequate method for quantifying grazing intensity in the field is to measure the amount of plant biomass removed over a fixed time period. This includes an estimate of plant production and assumes that biomass lost from decomposition and detachment 
is small over that time interval. The relationship between grazing by herbivorous fishes on $T$. testudinum and nutrient levels was estimated over a $9 \mathrm{~d}$ period starting in Week 7 of the experiment. Only the urchin exclosure plots at both sites were used to separate the effects of fish grazing from Lytechinus variegatus grazing. Initial leaf area was measured and converted to biomass ( $g$ dry $w t$ ) using a linear regression of biomass as the dependent variable and area as the independent variable in both the eutrophic $(y=a+b x$, $\mathrm{a}=8.07 \times 10^{-4}, b=5.08 \times 10^{-3}, \mathrm{R}^{2}=0.94, \mathrm{n}=51 \mathrm{j}$ and mesotrophic sites $\left(a=5.3 \times 10^{-3}, b=4.3 \times 10^{-3}, \mathrm{R}^{2}=\right.$ $0.94, n=82$ ). The tissue available to herbivorous fishes was calculated by combining the initial biomass estimates with the average biomass from new growth which was determined independently for the nutrientenriched and unenriched seagrass as described above. This value was compared to the final biomass measurements at the end of the $9 \mathrm{~d}$ period to determine the tissue lost ( $g$ dry wt $d^{-1}$ ) to herbivores for the different treatments. Grazing rates are reported on a per shoot basis, as tissue loss normalized to total available biomass ( $g$ dry wt $\mathrm{g}^{-1}$ dry wt $\mathrm{d}^{-1}$ ). Since the duration of the sampling interval was considerably less than that of leaf turnover $\left(2.7\right.$ to $4.2 \% \mathrm{~d}^{-1}$, Zieman et al. $1984 ; 1.2$ to $2.4 \% \mathrm{~d}^{-1}$, Tomasko \& Lapointe 1991), it is unlikely that tissue was lost via senescence.

Tissue nutrient content. Total carbon, nitrogen, and phosphorus concentrations of Thalassia testudinum were measured at 6 and $10 \mathrm{wk}$ to evaluate the differences in food quality among the treatments. At both times, 8 shoots from each plot were harvested and transported in seawater to the laboratory where the tissue was scraped clean of epiphytes and rinsed with deionized water before drying to a constant weight at $60^{\circ} \mathrm{C}$. These individual shoots were pooled for each plot and the treatment averages were determined from the 4 plots in each treatment. Because there was an increase in epiphyte cover on the $T$. testudinum in the nutrient enrichment treatments, epiphytes that were scraped from the seagrass blades were also rinsed and dried for tissue analysis. Samples were ground to a powder first with a mortar and pestle and then with a SPEX 8000 Mixer/Mill to ensure maximum homogenization of the material. Replicate tissue samples for phosphorus $(n=3)$ were analyzed for each plot using the colorimetric assay for $\mathrm{PO}_{4}^{3-}$ determination, after dry ashing at $550^{\circ} \mathrm{C}$ for $6 \mathrm{~h}$ and hot acid extraction for $2 \mathrm{~h}$ (modified from Stainton et al. 1974). Tissue carbon and nitrogen were determined in duplicate for each sample using a Carlo-Erba NA-1500 CNS analyzer, against an atropine standard. Tissue constituents are reported as percentage of sample dry weight.

Statistical analyses. The effects of the nutrient enrichment and grazing treatments on macrophyte abundance were determined from changes in percent cover for each species from the initial measurement to the $6 \mathrm{wk}$ and the final (10 wk) distributions. Comparisons among treatment means were made using ANOVA on the GLM procedure of Statistical Analysis Systems (SAS 1985). A Bonferroni adjustment was used to account for multiple tests ( 6 and $10 \mathrm{wk}$ ) on the same plots, where significance between treatments for the 6 and $10 \mathrm{wk}$ measurements was determined when $p<0.025$. All other data, unless otherwise noted, were compared using ANOVA (proc GLM) and StudentNewman-Keuls (SNK) preplanned comparisons of means, where significance was determined at $p<0.05$. Reported values represent means \pm 1 standard error (SE) throughout the text

\section{RESULTS}

\section{Nutrient concentrations and macrophyte distribution}

Dissolved inorganic nitrogen (DIN) concentrations in the inner part of Bailey's Bay were $2 \times$ higher than those at the outer bay site during the study period (Fig. 3; p $<0.0001$, ANOVA). These differences presumably resulted from groundwater influx and surface runoff to the inshore site, as nitrate levels were typically higher in the inner bay than in the outer bay. The SRP concentrations were at or below the detection limit throughout the study period, and thus there was no measurable phosphorus gradient in the water column within the bay (Fig. 3). Nutrient concentration data from 1989 and 1991 at the same locations showed a similar nutrient gradient within the bay, although nitrogen levels were higher in those years than in 1990 (McGlathery 1992a, b).

The distribution of Thalassia testudinum varied significantly as a function of distance from the shore (Fig. $4 ; p<0.02$. ANOVA). T. testudinum was absent in the innermost portion of the bay, but its percent cover increased with increasing distance from the eutrophic site (Fig. 4). There was also a marked difference in the macroalgal distribution along the nutrient gradient, with abundance declining with distance from the shore (Fig. 4ip $<0.0001$, ANOVA). In the eutrophic inner bay, the mat macroalga was the dominant component of the macrophyte community, with an average 40 to $65 \%$ cover across the transects, but was absent beyond $40 \mathrm{~m}$ from shore where nutrient concentrations were lower (Fig. 4). Densities of Lytechinus variegatus and herbivorous fishes were similar at both sites within the bay (Table 1), although fish abundances were probably underestimated by the visual survey since Sparisoma radians is cryptic and 

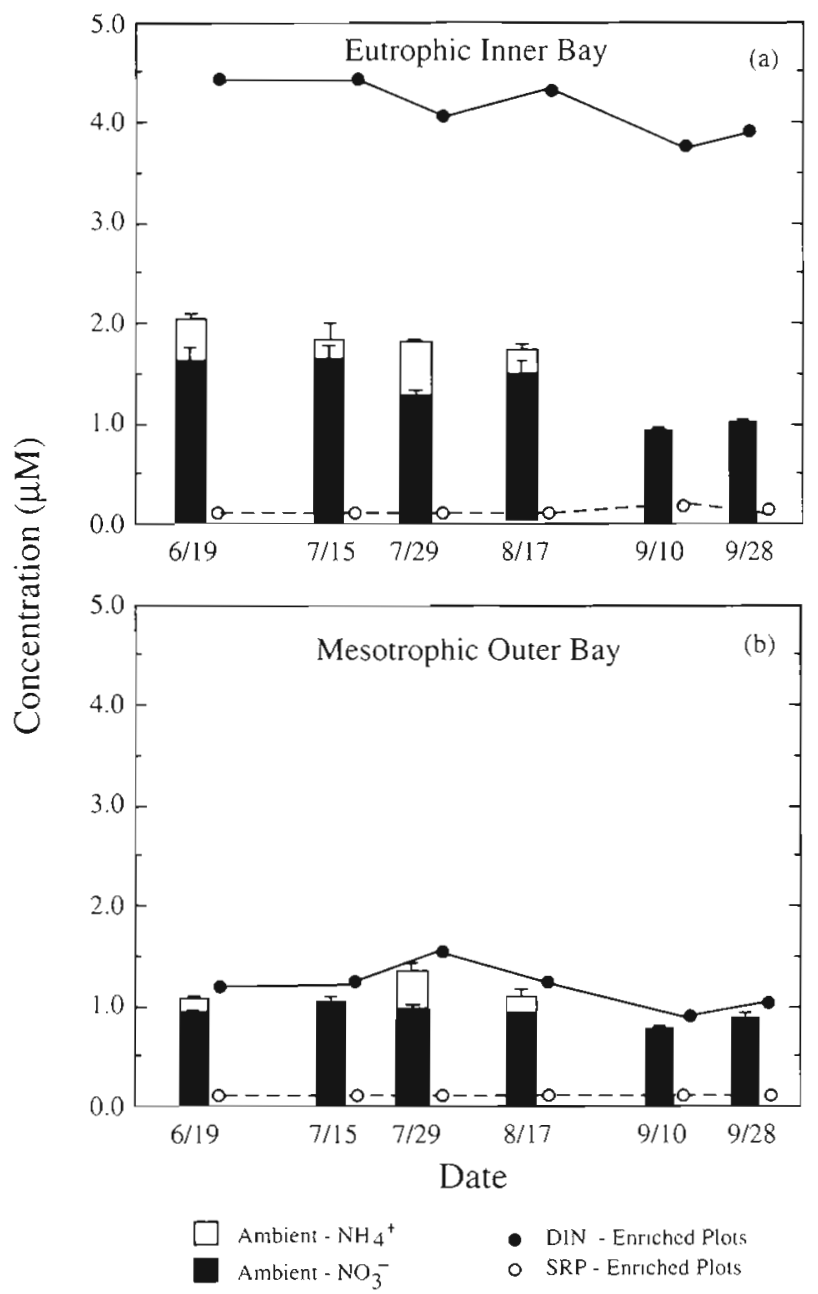

Fig. 3. Ambient ammonium and nitrate concentrations in the water column in (a) the eutrophic inner site and (b) the mesotrophic outer site in Bailey's Bay in 1990. Values are means ( $\pm 1 \mathrm{SE}$ ) of triplicate bottle samples taken within $1 \mathrm{~h}$ of low tide. Triplicate samples were run as analytical replicates on each bottle. Ambient SRP concentrations were always at or below the detection limit $(0.05 \mu \mathrm{M})$ and so do not appear on the graph. The increases in DIN and SRP levels in the fertilization plots are shown for each site

often hides among the macrophytes close to the sediment.

\section{Nutrient versus grazing effects}

Nutrient enrichment resulted in an increase in both nitrogen and phosphorus in the water column of the treatment plots. At the eutrophic site, there was a 10 fold increase in ammonium concentrations over levels in the unenriched plots $(2.80 \pm 1.21$ vs $0.23 \pm 0.04 \mu \mathrm{M})$ and at least a 3 -fold increase in SRP concentrations $(0.17 \pm 0.04$ vs $<0.05 \mu \mathrm{M})$. The enrichment effect was less pronounced at the mesotrophic site; both ammo- nium $(0.30 \pm 0.24$ vs $0.15 \pm 0.08 \mu \mathrm{M})$ and SRP $(0.10 \pm$ 0.002 vs $0.05 \pm 0.01 \mu \mathrm{M}$ ) concentrations were twice those in the unenriched plots. This was probably due to dilution into a large volume of water in the mesotrophic outer bay where current velocities were slightly higher, as the fertilizer stakes were often observed to dissolve faster at the mesotrophic site. Overall, fertilization increased available DIN by more than $2 \times$ at the eutrophic site, but only by about $10 \%$ at the mesotrophic site (Fig. 3).

The unmanipulated control plots and the caged 'control' plots (no nutrient, no urchin) at both sites were similar in terms of the change in percent occurrence of the macrophyte species ( $p>0.05, t$-test), indicating that there was no obvious effect of the enclosure/exclosure cages on the macrophyte distribution over the study period. In addition, Thalassia testudinum leaf area and aboveground biomass were not significantly different between the caged and unmanipulated control plots at either site (Table 2; p > 0.05, $t$-test). The cages also had no obvious effect on foraging by herbivorous fishes, as average grazing losses in the unmanipulated control plots $(0.049 \pm 0.008$ for the eutrophic site; $0.032 \pm 0.002$ for the mesotrophic site) were not significantly different from grazing losses in the caged controls (Table 3; p > 0.05, $t$-test for both sites).

At the eutrophic site, experimental nutrient enrichment had a significant effect on the percent cover of the mat macroalga (Fig. 5a). Treatment differences were apparent at $10 \mathrm{wk}$ when the average cover of Spyridea hypnoides had increased by 60 to $100 \%$ rela-

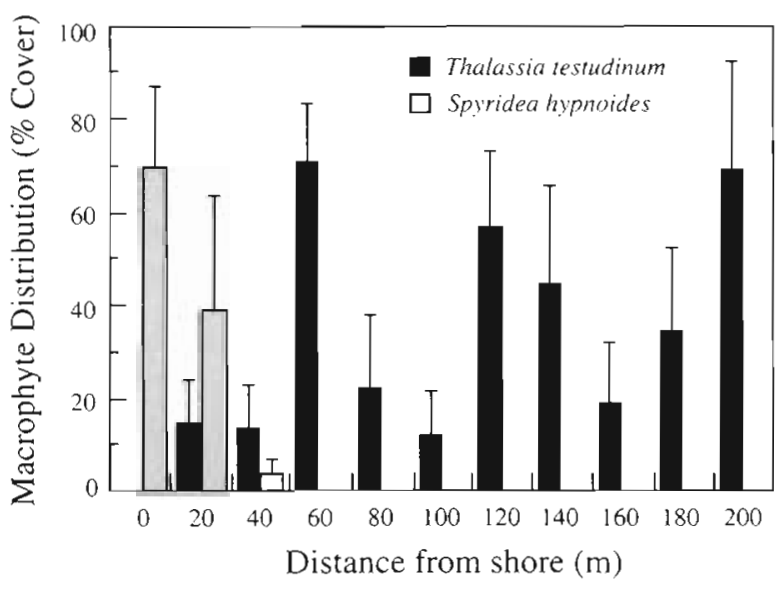

Fig. 4. Distribution of the seagrass Thalassia testudinum (solid bars) and the mat-forming macroalga Spyridea hypnoides (open bars) as a function of distance from the shore, measured as percent occurrence in $0.25 \mathrm{~m}^{2}$ plots along 4 parallel transects. Two transects were located $10 \mathrm{~m}$ apart on either side of the bay, thus avoiding the deeper dredged center, and extended from the eutrophic inner bay $(0 \mathrm{~m})$ to the mesotrophic outer bay $(200 \mathrm{~m})$. Values are means $\pm 1 \mathrm{SE}$ 
Table 2. Thalassia testudinum. Aboveground biomass estimates of seagrass in Bailey's Bay at the end of the 10 wk enrichment grazing experiment. Values are means ( $S E$ in parentheses, $n=4$ ). gdw: $g$ dry wt

\begin{tabular}{|llrr|}
\hline Location & \multicolumn{1}{c}{ Treatment } & $\begin{array}{c}\text { Leaf area } \\
\left(\mathrm{cm}^{2} \text { shoot }\right.\end{array}$ & \multicolumn{1}{c|}{$\begin{array}{c}\text { Biomass } \\
\left(\mathrm{gdw} \mathrm{m}^{-2}\right)\end{array}$} \\
\hline Eutrophic & +Nutrients, +urchins & $6.7(1.1)$ & $2.5(1.0)$ \\
inner bay & +Nutrients, no urchins & $3.5(1.0)$ & $1.8(0.6)$ \\
& No nutrients, +urchins & $17.1(2.8)$ & $25.4(4.1)$ \\
& No nutrients, no urchins & $26.6(3.7)$ & $15.5(5.6)$ \\
& Unmanipulated control & $19.5(1.2)$ & $28.0(2.5)$ \\
Mesotrophic & +Nutrients, +urchins & $7.9(1.6)$ & $7.3(2.9)$ \\
outer bay & +Nutrients, no urchins & $26.1(1.3)$ & $16.9(8.0)$ \\
& No nutrients, +urchins & $11.0(1.6)$ & $4.5(0.7)$ \\
& No nutrients, no urchins & $21.15(4.1)$ & $21.1(2.7)$ \\
& Unmanipulated control & $29.71(2.0)$ & $18.5(1.5)$ \\
\hline
\end{tabular}

tive to the starting values (Fig. 5a; $\mathrm{p}<$ 0.001, ANOVA). Grazing by urchins or by herbivorous fishes did not affect $S$. hypnoides distribution at this site (Fig. 5ai $p<0.05$, ANOVA). There was a significant negative effect of nutrient enrichment on Thalassia testudinum percent cover after 6 wk at the eutrophic site (Fig. 5b; p $<0.025$, ANOVA). This impact was largely due to the severe reduction of $T$. testudinum distribution in the +nutrient, no urchin treatment, which was evident in both the 6 and $10 \mathrm{wk}$ measurements (Fig. 5b). Nutrient enrichment in the absence of urchin grazing resulted in a nearly 30 -fold reduction of $T$. testu-

Eutrophic Inner Bay

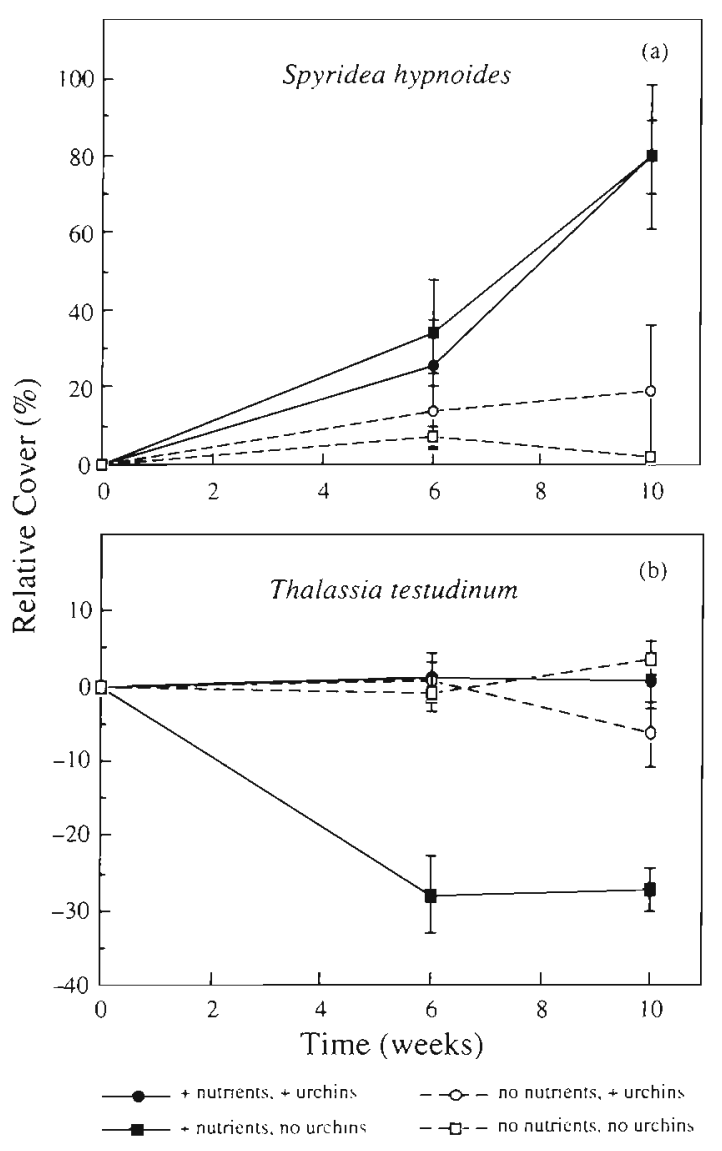

Fig. 5. Relative cover of (a) the mat-forming macroalga Spyridea hypnoides and (b) the seagrass Thalassia testudinum ( $\pm 1 \mathrm{SE}$ ) subject to nutrient enrichment and grazing treatments in the eutrophic inner bay. Treatment effects were determined as the change in the frequency distribution in $0.25 \mathrm{~m}^{2}$ plots from initial distribution measurements. Relative cover of $S$. hypnoides and $T$. testudinum at $10 \mathrm{wk}$ in the caged control treatment (no nutrients, no urchins) did not differ from the unmanipulated (cageless) controls (not shown) ( $p>0.05, t$-test) dinum percent cover compared to the other 3 treatments ( $p<0.0001$, SNK comparison of means) and a 10 -fold decrease in aboveground biomass (Table 2; $p<0.01$, SNK comparison of means). There was also a significant urchin effect on $T$. testudinum percent cover after 6 wk at the eutrophic site (Fig. 5b; $\mathrm{p}<0.025$, ANOVA). This was the result of $T$. testudinum shoots in the +nutrient, no urchin treatment being grazed below the sediment surface by herbivorous fishes and thus not being counted in the frequency distribution measure, since the reductions in leaf area and aboveground biomass were similar in both treatments (Table 2; $p>0.05$, ANOVA).

There was no significant change in the percent cover of Thalassia testudinum at the mesotrophic site during the experiment as a result of urchin grazing or nutrient levels (Fig. $6 ; p>0.05$, ANOVA), perhaps due in part to the lower enrichment effect at this site. There was, however, a significant reduction in aboveground biomass and leaf area of $T$. testudinum in the +urchin treatments (Table $2 ; \mathrm{p}<0.01$ and 0.001 , respectively,

Table 3. Thalassia testudinum. Comparison of growth rates and tissue loss due to grazing by herbivorous fishes for the dominant seagrass. Values represent means ( $\pm 1 \mathrm{SE}, \mathrm{n}=3$ to 7) of either new growth or grazing loss normalized to total shoot biomass

\begin{tabular}{|lcc|}
\hline Treatment & $\begin{array}{c}\text { Growth } \\
\left(\mathrm{g} \text { dry wt } \mathrm{g}^{-1}\right.\end{array}$ & $\begin{array}{c}\text { Grazing loss } \\
\left.\text { dry } \mathrm{d}^{-1}\right)\end{array}$ \\
\hline $\begin{array}{l}\text { Eutrophic inner bay } \\
\text { +Nutrients }\end{array}$ & $0.046(0.023)$ & $0.109(0.002)$ \\
$\quad$ No nutrients & $0.042(0.006)$ & $0.029(0.011)$ \\
$\quad$-test & $\mathrm{p}>0.05$ & $\mathrm{p}<0.0001$ \\
$\begin{array}{l}\text { Mesotrophic outer bay } \\
\text { +Nutrients }\end{array}$ & $0.036(0.010)$ & $0.049(0.008)$ \\
No nutrients & $0.036(0.004)$ & $0.035(0.003)$ \\
$t$-test & $\mathrm{p}>0.05$ & $\mathrm{p}<0.07$ \\
\hline
\end{tabular}




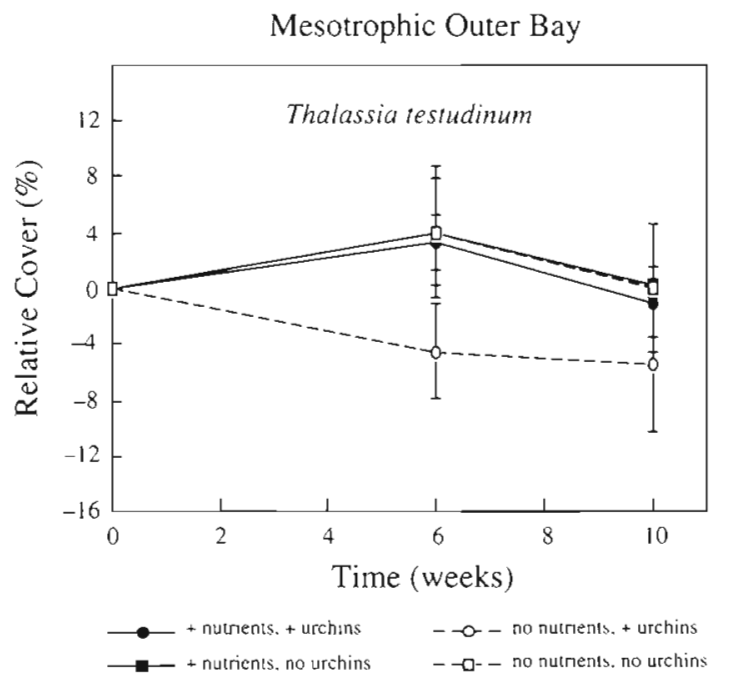

Fig. 6. Thalassia testudinum. Relative cover (mean change in percent cover $\pm 1 \mathrm{SE}$ ) for seagrass in the mesotrophic outer bay. Caged controls and unmanipulated cageless controls did not differ at $10 \mathrm{wk}$ ( $\mathrm{p}>0.05$, $t$-test)

ANOVA), which was unrelated to nutrient conditions (Table $2 ; \mathrm{p}>0.05$, ANOVA). The mat macroalgae did not appear in the fertilization treatments in the mesotrophic site as expected. This could have resulted from several factors including a higher dissolution of added nutrients, insufficient time for colonization, or the impact of grazing on macroalgal recruitment.

\section{Grazing pressure on Thalassia testudinum}

The decline in the percent occurrence of Thalassia testudinum in the +nutrient, no urchin plots in the eutrophic inner bay could be attributed either to increased grazing pressure by herbivorous fishes on the nutrient-enriched seagrass or to decreased growth caused by light attenuation from enhanced macroalgal and epiphytic biomass. Growth rates and grazing loss for $T$. testudinum over a $9 \mathrm{~d}$ period (Week 7) are compared in Table 3. Only the urchin exclosure treatments were used in this measure to ensure that the grazing rates represented loss due to fish and not to urchin herbivory. Grazing loss in the +nutrient treatments was approximately 4 -fold higher ( $p<0.0001, t$-test) than in the unenriched plots. Growth rates, as measured by leaf elongation, were not significantly different between the +nutrient and no nutrient plots ( $\mathrm{p}>0.05$, $t$-test), indicating that the decline in $T$. testudinum leaf area was not due to lower growth in the +nutrient treatments during this short-term measure. This
Table 4. Thalassia testudinum. Light-saturated photosynthesis $\left(P_{\max }\right)$ and respiration of seagrass at the end of the $10 \mathrm{wk}$ enrichment grazing experiment (SE in parentheses, $n=3$ to 9 )

\begin{tabular}{|c|c|c|}
\hline Treatment & \multicolumn{2}{|c|}{$\begin{array}{l}P_{\max } \quad \text { Respiration } \\
\left(\mu \mathrm{mol} \mathrm{O}_{2} \mathrm{dm}^{-2} \mathrm{~min}^{-1}\right)\end{array}$} \\
\hline \multicolumn{3}{|c|}{ Eutrophic inner bay } \\
\hline+ Nutrients & $0.57 \quad(0.08)$ & $0.36 \quad(0.07)$ \\
\hline No nutrients & $0.45(0.03)$ & $0.44 \quad(0.01)$ \\
\hline$t$-test & $\mathrm{p}>0.05$ & $p>0.05$ \\
\hline \multicolumn{3}{|c|}{ Mesotrophic outer bay } \\
\hline+ Nutrients & $0.42(0)$ & $0.30(0.01)$ \\
\hline No nutrients & $0.42(0.06)$ & $0.30(0.03)$ \\
\hline$t$-test & $p>0.05$ & $p>0.05$ \\
\hline
\end{tabular}

was also evident in the $P_{\max }$ and respiration measurements, which were similar among all treatments (Table $4 ; \mathrm{p}>0.05$, $t$-test).

A similar pattern was seen at the mesotrophic site, with a trend toward increased grazing pressure on nutrient-enriched plants (Table $3 ; \mathrm{p}<0.07$, $t$-test) and similar rates of leaf-specific growth and productivity (Tables $3 \& 4 ; \mathrm{p}>0.05$, $t$-test).

\section{Tissue nutrient content}

There was significant treatment variation within each site only for the $\mathrm{N}$ content of the Thalassia testudinum leaf tissue (Table 5). Nutrient enrichment resulted in a $25 \%$ increase in the $\mathrm{N}$ content for the inner bay plants and a $12 \%$ increase for the outer bay plants $(\mathrm{p}<0.0001$ for eutrophic site; $\mathrm{p}<0.001$ for mesotrophic site, ANOVA). Between sites, the C content of

Table 5. Thalassia testudinum. Tissue nutrient content of seagrass for the 4 nutrient-grazing treatment combinations at both locations in Bailey's Bay. Elemental concentrations of carbon, nitrogen, and phosphorus were determined as the percentage of sample dry weight (SE in parentheses, $n=3$ to 8 )

\begin{tabular}{|lccc|}
\hline Treatment & $\% \mathrm{C}$ & $\% \mathrm{~N}$ & $\% \mathrm{P}$ \\
\hline Eutrophic inner bay & & & \\
+ Nutrients, +urchins & $33.29(0.31)$ & $2.41(0.09)$ & $0.18(0.010)$ \\
+ Nutrients, no urchins & $34.17(0.32)$ & $2.81(0.12)$ & $0.19(0.008)$ \\
No nutrients, +urchins & $33.17(0.21)$ & $1.93(0.00)$ & $0.17(0.006)$ \\
No nutrients, no urchins & $33.11(0.19)$ & $2.02(0.05)$ & $0.17(0.007)$ \\
Unmanipulated control & $33.41(0.27)$ & $2.11(0.05)$ & $0.19(0.005)$ \\
Mesotrophic outer bay & & & \\
+ Nutrients, +urchins & $34.19(0.67)$ & $2.21(0.08)$ & $0.15(0.018)$ \\
+ Nutrients, no urchins & $33.08(0.35)$ & $2.14(0.09)$ & $0.14(0.010)$ \\
No nutrients, +urchins & $33.47(0.28)$ & $1.91(0.06)$ & $0.13(0.005)$ \\
No nutrients, no urchins & $33.84(0.17)$ & $1.91(0.03)$ & $0.12(0.008)$ \\
Unmanipulated control & $34.06(0.24)$ & $1.89(0.05)$ & $0.13(0.005)$ \\
& & & \\
\hline
\end{tabular}


the $T$. testudinum tissue was similar ( $p>0.05$, ANOVA), but both the $N$ and $P$ contents were significantly higher at the eutrophic site than at the mesotrophic site $(\mathrm{p}<$ 0.001 , ANOVA). Since there was no significant difference in the tissue nutrient content between seagrasses harvested at 6 and $10 \mathrm{wk}(\mathrm{p}>0.05$. ANOVA), the analysis of treatment differences both within and between sites was based on pooled samples from the 2 sampling periods. T. testudinum leaf tissue from the caged and unmanipulated control plots had similar $C$, $\mathrm{N}$, and $\mathrm{P}$ contents (Table $5 ; \mathrm{p}>0.05$, ANOVA).

Filamentous epiphytes harvested from the Thalassia testudinum blades in the enriched treatments at the eutrophic site had a high $\mathrm{N}$ content $(3.07 \pm 0.28$ wt $\%$, $\mathrm{n}=3$ ), approximately $15 \%$ higher than the nutrientenriched seagrasses and $35 \%$ more than the unenriched seagrasses during the experiment. The $\mathrm{C}$ content ( $36.35 \pm 0.49 \mathrm{wt} \%, \mathrm{n}=3$ ) was also slightly higher than that of the seagrasses, probably due to fine sediment associated with the epiphyte filaments on the seagrass blades. Overall, the relative $\mathrm{N}$ content of the epiphytes was similar to that of the enriched seagrasses, with a C: $\mathrm{N}$ ratio of $14.07 \pm 1.12$.

\section{DISCUSSION}

Nutrient enrichment caused an increase in the percent cover of the filamentous macroalga Spyridea hypnoides at the eutrophic site in Bailey's Bay. Depending on initial distribution, S. hypnoides abundance increased by 60 to $100 \%$ in the experimentally enriched plots, without significant herbivore effects. This response is consistent with the dominance of this macroalga in the eutrophic inner bay where ambient water column DIN levels were typically $2 \times$ higher than those at the mesotrophic site, and with other recent studies relating increased macroalgal biomass in coastal bays to elevated inputs of nitrogen-rich groundwaters (Florida Bay, Florida, USA, Lapointe et al. 1990; Waquoit Bay, Massachusetts, USA, Valiela et al. 1992). In Bermuda, human population densities are high, and the use of open cesspits for domestic wastewater disposal enriches groundwater primarily in nitrate (Simmons et al. 1985). Nitrate levels were consistently higher at the eutrophic site than at the outer mesotrophic site, and were similar to those reported for another groundwater-fed subtropical system $(2.32 \pm$ $1.28 \mu \mathrm{M}$, Big Pine Key, Florida; Tomasko \& Lapointe 1991). The high summer levels of nitrate at the eutrophic site probably reflect elevated groundwater inputs (McGlathery 1992b) when seasonally high rainfall increases groundwater recharge and intrusion into nearshore waters. Both nitrate and ammonium concentrations decreased during the fall, a pattern also observed by Lapointe (1989) in a similar system (South Pine Channel, Florida Bay) and correlated to seasonal variability in rainfall and to a possible reduction in nitrogen fixation rates

The increase in Spyridea hypnoides following experimental nutrient enrichment at the eutrophic site is also consistent with previous work showing that this species has rapid nutrient uptake and growth potentials, enabling it to take advantage of high water column nutrient concentrations (McGlathery 1992a). Many filamentous macroalgae such as $S$. hypnoides have little biomass allocated to structural material at the expense of photosynthetic tissue, and can rapidly exploit nutrient resources (Littler \& Littler 1980, Carpenter 1990). S. hypnoides did not appear in the nutrient enrichment treatments in the mesotrophic outer bay as expected. The most likely explanation for this lack of response is that nutrient availability at the mesotrophic site, even after enrichment, may have been below that required to sustain macroalgal growth. Fertilization was less effective at the mesotrophic site, probably due to higher dilution of added nutrients in a greater current flow. As a result, DIN levels in the fertilized plots were not significantly changed from ambient conditions and were 2 to $4 \times$ lower than concentrations in both the enriched and unenriched plots at the eutrophic site. McGlathery (1992a) showed that $S$. hypnoides has a high nitrogen demand for growth, and at ambient nutrient levels at the mesotrophic site transplants from the eutrophic site showed clear signs of physiological stress associated with nitrogen deprivation after $2 \mathrm{wk}$. Under natural conditions, S. hypnoides apparently was absent from the mesotrophic site because it was unable to meet its nitrogen demands at low ambient concentrations (McGlathery 1992a). An alternative explanation for the lack of fertilization effect at the mesotrophic site is that grazing limited macroalgal recruitment. Mesograzers (amphipods, small gastropods) consume significant quantities of epiphyte biomass on seagrass blades and macroalgal fronds (Klumpp et al. 1992. Neckles et al. 1993, Williams \& Ruckelshaus 1993), and may also consume macroalgal filaments. GeertzHansen et al. (1993) suggested that grazing by mesoherbivores, primarily the isopods Idotea spp., was partly responsible for seasonal patterns in the distribution of the sheet-like macroalga Ulva lactuca in a temperate estuary.

An indirect effect of nutrient enrichment was the marked loss of Thalassia testudinum aboveground biomass in the fertilization treatments in the eutrophic inner bay, especially in the urchin exclosure treatments. This effect could be the result of either reduced growth or increased grazing pressure by herbivorous fishes. Light attenuation from excessive planktonic 
and epiphytic growth has been shown to decrease the abundance of both temperate and tropical seagrasses in eutrophic environments (Bulthuis \& Woelkerling 1983, van Montfrans et al. 1984, Borum 1985. Twilley et al. 1985, van Vierssen \& Prins 1985, Cambridge et al. 1986, Tomasko \& Lapointe 1991). Enhanced macroalgal growth in high nutrient coastal habitats also has been correlated with the loss of extensive seagrass meadows in Bermuda (von Bodungen et al. 1982) and Massachusetts (Valiela et al. 1990). In Bailey's Bay, the negative correlation between Spyridea hypnoides and Thalassia testudinum abundance in the eutrophic inner bay suggests that shading by the mat-forming macroalga may have reduced seagrass abundance at this site. However, there was no direct evidence of a shading effect in the $10 \mathrm{wk}$ enrichment experiment at the eutrophic site, either in reduced growth or as changes in photosynthesis and respiration rates between treatments. This may be because accumulations of macroalgae in the enrichment experiment were patchy, causing short-term localized shading. In situations where the stress is imposed on a small enough scale (i.e. at the level of individual shoots), clonal integration of seagrass shoots can mediate the effects of localized light limitation. Tomasko \& Dawes (1989) showed that rhizome reserves and the transfer of metabolites from unshaded shoots, rather than photosynthesis, supported T. testudinum production in the short term (2 wk) when individual shoots were shaded. However, this does not preclude the possibility that over the long term shading by dense widespread macroalgal mats could deplete rhizome reserves and reduce seagrass growth and shoot density.

Although the short-term ( $9 \mathrm{~d}$ to $10 \mathrm{wk}$ ) productivity measurements may be insufficient to detect longerterm shading effects, they do indicate that the reduction in aboveground biomass of Thalassia testudinum at the eutrophic site during the enrichment experiment was not due to lower growth rates. Instead, it was the intense grazing by herbivorous fishes in response to fertilization that caused the severe loss of $T$. testudinum shoot biomass at the eutrophic site. In the shortterm grazing assay, nearly $100 \%$ of the total aboveground biomass was removed by herbivorous fishes after $9 \mathrm{~d}$ in the enriched sites, while only $26 \%$ was lost to grazing in the sites without nutrient additions. This level of herbivory on $T$. testudinum in areas with elevated nutrients is considerably higher than that reported by Ogden (1980) in an oligotrophic Caribbean seagrass bed, where typically 5 to $10 \%$ of daily net primary production was directly consumed by herbivores (primarily Sparisoma radians).

It appears that the increased grazing pressure by herbivorous fishes on Thalassia testudinum in the fertilization treatments at the eutrophic site was in response to the higher nitrogen content of the seagrass and its associated epiphytes. Enrichment at the eutrophic site caused a significant increase only in seagrass nitrogen levels. There was no similar increase in tissue phosphorus content, perhaps because the availability of added phosphate was lower due to adsorption by the carbonate sediments (Morse et al. 1985) or because the seagrass was saturated with respect to phosphorus at the eutrophic site (McGlathery et al. 1994). The high phosphorus content of $T$. testudinum at the eutrophic site is among the highest reported for this species (Powell et al. 1989, Duarte 1990, Fourqurean et al. 1992). The enriched seagrass blades were also covered with a thick coating of filamentous epiphytes with a higher nitrogen content than the calcareous red algae typically colonizing seagrasses in oligotrophic habitats (Lobel \& Ogden 1981). Herbivorous fishes feeding on these epiphyte-covered seagrasses at the eutrophic site would ingest at least $40 \%$ more nitrogen than by feeding on the unenriched blades without extensive epiphyte cover. Several species of temperate fish also have been shown to preferentially graze on high-nitrogen food sources in the laboratory, although the proximate cue influencing selectivity is not known (Horn 1989). The pattern of increased grazing pressure on higher-nitrogen $T$. testudinum was also evident between treatments at the mesotrophic site and between sites on enriched plants, although consumption of enriched plants was lower in the outer bay. An alternative explanation for the difference in grazing pressure that is independent of nutrient content, either between sites or between treatments, is that increased macroalgal biomass provided more refuge for herbivorous fishes. Both seagrasses and macroalgae can provide hiding places from predators and support higher abundances of herbivorous fish compared to unvegetated sediments (Lenanton et al. 1982, Orth et al. 1984). However, there was no difference in the grazing pressure on unfertilized seagrasses between the eutrophic and mesotrophic sites which would be expected if grazer abundance and feeding activity was a function of the provision of refugia by macroalgae. An increase in macroalgal cover also could not account for the difference between treatments at the mesotrophic site, and though macroalgal cover increased in response to fertilization at the eutrophic site, this was largely offset by a substantial loss in seagrass cover There was no similar response of increased grazing on nutrient-enriched seagrass blades by the urchins, perhaps because Lytechinus variegatus has a more diverse diet than the herbivorous fishes, feeding more on epiphytes and detritus than on live seagrass blades (Vadas et al. 1982, Keller 1983). It was only in the mesotrophic outer bay site, where epiphyte loads and availability of detritus were 
lower, that the urchins reduced $T$, testudinum aboveground biomass.

The higher consumption by herbivorous fishes on epiphyte-covered Thalassia testudinum blades in response to an increase in food quality indicates that there was an interaction between herbivore and nutrient effects in this system. This response is consistent with fertilization studies in other systems showing enhanced grazing by insects in mangrove (Onuf et al. 1977) and terrestrial communities (Room et al. 1989, Mickenberg \& Ottenheim 1990), and by insects (Vince et al. 1981) and mammals (Valiela et al. 1985) in salt marsh communities. In Bailey's Bay, intense consumption by herbivorous fishes of high-nitrogen $T$. testudinum blades at the eutrophic site created small scale $\left(<1 \mathrm{~m}^{2}\right)$ patches in the seagrass bed which were similar to those naturally occurring in areas presumed to be localized groundwater seeps (McGlathery 1992a); these patches were absent from the mesotrophic site where groundwater nutrient influx was minimal. The impact of this intense grazing on the seagrass community may be largely time-dependent; short-term responses may be manifested as changes in species abundance (cover, biomass; quantitative effects sensu Menge 1992), whereas long-term effects may be reflected in species composition changes (qualitative effects sensu Menge 1992). This study documents a short-term effect where herbivorous fishes consumed a large fraction of seagrass aboveground biomass only at the eutrophic site in response to a transient increase in food quality, but this intense consumption was limited to small areas of high external nutrient inputs. For this response to be sustained over the long term, intense herbivory must be severe enough to damage the basal meristem or constant over the long term in order to deplete belowground rhizome reserves and prevent seagrass regrowth. However, like terrestrial plants that are differentiated into above- and belowground parts, $T$. testudinum is generally resilient to repeated cropping (Greenway 1974, 1976, Thayer et al. 1984, Valentine \& Heck 1991). It is more likely that herbivory in this system acts as a disturbance on a shorter time scale (Carpenter 1986), limiting consumer effects on the community to the creation of grazing patches in response to resource heterogeneity. This is in agreement with Strong (1992) that consumer control is more common in human-perturbed habitats and that ecological complexity, in this case nutrient heterogeneity and morphological differentiation, may buffer against a more widespread impact of consumption in natural communities.

Acknowledgements. R. Howarth and R. Marino provided comments on an earlier version of the manuscript. R. Marino, D. Westphalen and S. R. Smith assisted in the laboratory and field work. Partial funding for the project was provided by the
Samuel Riker and Roger Stone Fellowships from the Bermuda Biological Station for Research. This is contribution no. 1373 from the Bermuda Biological Station for Research.

\section{LITERATURE CITED}

Borowitzka MA (1972) Intertidal algal species diversity and the effect of pollution. Aust $J$ mar Freshwat Res 23:73-84

Borum J (1985) Development of epiphytic communities on eelgrass (Zostera marina) along a nutrient gradient in a Danish estuary. Mar Biol 87:211-218

Bulthuis DA, Woelkerling WJ (1983) Biomass accumulation and shading effects of epiphytes on leaves of the seagrass Heterozostera tasmanica in Victoria, Australia. Aquat Bot $16: 137-148$

Cambridge MC, Chaffings AW, Brittan C, Moore L, McComb AJ (1986) The loss of seagrass in Cockburn Sound, Western Australia. II. Possible causes of seagrass decline. Aquat Bot 24:269-285

Carpenter RC (1986) Partitioning herbivory and its effects on coral reef algal communities. Ecol Monogr 56:345-363

Carpenter RC (1990) Competition among marine macroalgae: a physiological perspective. J Phycol 26:6-12

Duarte CM (1990) Seagrass nutrient content. Mar Ecol Prog Ser 67:201-207

Fourqurean JW, Zieman JC, Powell GVN (1992) Phosphorus limitation of primary production in Florida Bay: evidence from the C:N:P ratios of the dominant seagrass Thalassia testudinum. Limnol Oceanogr 37:162-171

Fujita RM (1985) The role of nitrogen status in regulating transient ammonium uptake and nitrogen storage by macroalgae. J exp mar Biol Ecol 92:283-301

Gappa JJL, Tablado A, Magaldi NH (1990) Influence of sewage pollution on a rocky intertidal community dominated by the mytilid Brachidontes rodriguezi. Mar Ecol Prog Ser 63:163-175

Geertz-Hansen O, Sand-Jensen K, Hansen DF, Christiansen A (1993) Growth and grazing control of abundance of the marine macroalga, Ulva lactuca L. in a eutrophic Danish estuary. Aquat Bot 46:101-109

Grasshoff K. Erhardt M. Kremling K (1983) Methods of seawater analysis. Verlag Chemie, Weinheim

Greenway M (1974) The effects of cropping on the growth of Thalassia testudinum (Konig) in Jamaica. Aquaculture $4: 199-206$

Greenway $M$ (1976) The grazing of Thalassia testudinum in Kingston Harbour, Jamaica. Aquat Bot 2:117-126

Hay ME (1991) Fish-seaweed interactions on coral reefs; effects of herbivorous fishes and adaptations of their prey. In: Sale PF (ed) The ecology of fishes on coral reefs. Academic Press, New York, p 96-119

Hay ME, Colburn T, Downing D (1983) Spatial and temporal patterns in herbivory on a Caribbean fringing reef: the effects on plant distribution. Oecologia 58:299-308

Horn MH (1989) Biology of marine herbivorous fishes. Oceanogr mar Biol A Rev 27:167-272

Hunter MD, Price PW (1992) Playing chutes and ladders: bottom-up and top-down forces in natural communities. Ecology 73:724-732

Keller BD (1983) Coexistence of sea urchins in seagrass meadows: an experimental analysis of competition and predation. Ecology 64:1581-1598

Klumpp DW, Salita-Espinosa JS, Fortes MD (1992) The role of epiphytic periphyton and macroinvertebrate grazers in the trophic flux of a tropical seagrass community. Aquat Bot 43:327-349 
Lapointe BE (1989) Macroalgal production and nutrient relations in oligotrophic areas of Florida Bay. Bull mar Sci 44:312-323

Lapointe BE, O'Connell JD, Garrett GS (1990) Nutrient couplings between on-site sewage disposal systems, ground waters, and nearshore surface waters of the Florida Keys Biogeochemistry 10:289-307

Lenanton RCJ, Robertson Al, Hansen JA (1982) Nearshore accumulations of detached macrophytes as nursery areas for fish. Mar Ecol Prog Ser 9:51-57

Littler MM, Littler DS (1980) The evolution of thallus form and survival strategies in benthic macroalgae: field and laboratory tests of a functional form model. Am Nat $116: 25-44$

Lobel PS, Ogden JC (1981) Foraging by the herbivorous parrotfish Sparisoma radians. Mar Biol 64:173-183

Lubchenco J, Gaines SD (1981) A unified approach to marine plant-herbivore interactions. I. Populations and communities A Rev Ecol Syst 12:405-437

McComb AJ, Atkins RP, Birch PB, Gordon DM, Lukatelich RJ (1981) Eutrophication in the Peel-Harvey Estuarine System, Western Australia. In: Neilson BJ, Cronin LE (eds) Estuaries and nutrients. Humana Press, Clifton, NJ

McGlathery KJ (1992a) Physiological controls on the distribution of the macroalga Spyridea hypnoides: patterns along a eutrophication gradient in Bermuda. Mar Ecol Prog Ser $87: 173-182$

McGlathery KJ (1992b) Nutrient and herbivore influences on seagrass community dynamics. PhD dissertation, Cornell University, Ithaca, NY

McGlathery KJ, Marino R, Howarth RW (1994) Variable rates of phosphate uptake by shallow marine carbonate sediments: mechanisms and ecological significance. Biogeochemistry 25:127-146

Menge BA (1992) Community regulation: under what conditions are bottom-up factors important on rocky shores? Ecology 73:755-765

Mickenberg OPJM, Ottenheim JJGW (1990) Effect of leaf nitrogen content of tomato plants on preference and performance of a leaf mining fly. Oecologia 83:291-298

Morse JW, Zullig JJ, Bernstein LD, Millero FJ, Milne P, Mucci A. Choppin GR (1985) Chemistry of calcium carbonaterich shallow water sediments in the Bahamas. Am J Sci 285:147-185

Murray SN, Littler MM (1978) Analysis of seaweed communities in a disturbed rocky intertidal environment near Whites Point, Los Angeles. Calif., USA. Hydrobiologia 116/117:374-382

Neckles HA, Wetzel RW, Orth RJ (1993) Relative effects of nutrient enrichment and grazing on epiphyte-macrophyte (Zostera marina L.) dynamics. Oecologia 93:285-295

Ogden JC (1980) Faunal relationships in Caribbean seagrass beds. In: Phillips RC, McRoy CP (eds) Handbook of seagrass biology. Garland Press, New York, p 173-198

Onuf CP, Teal JM, Valiela I (1977) Interactions of nutrients, plant growth and herbivory in a mangrove ecosystem. Ecology 58:514-526

Orth RJ, Heck JKL, Van Montfrans J (1984) Faunal communities in seagrass beds: a review of the influence of plant structure and prey characteristics on predator-prey relationships. Estuaries 7:339-350

Powell GVN, Kenworthy WJ, Fourqurean JW (1989) Experimental evidence for nutrient limitation of seagrass growth in a tropical estuary with restricted circulation. Bull mar Sci 44:324-340

Power ME (1992) Top-down and bottom-up forces in foodwebs: do plants have primacy? Ecology 73:733-746
Randall JE (1967) Food habits of reef fishes of the West Indies. Stud Trop Oceanogr, Miami 5:665-847

Room PM, Julien MH, Forno IW (1989) Vigorous plants suffer most from herbivores: latitude, nitrogen, and biological control of the weed Salvinia molesta. Oikos 54:92-100

Sand-Jensen K (1977) Effect of epiphytes on eelgrass photosynthesis. Aquat Bot 3:55-64

Sand-Jensen K, Revsbech NP, Jorgensen BB (1985) Microprofiles of oxygen in epiphyte communities on submerged macrophytes. Mar Biol 89:55-62

SAS (1985) SAS user's guide: statistics. SAS Institute, Cary, $\mathrm{NC}$

Simmons JAK, Jickells T, Knap A, Lyons WB (1985) Nutrient concentrations in groundwaters from Bermuda: anthropogenic effects. In: Caldwell DE, Brierly JA (eds) Planetary ecology. Van Nostrand Reinhold, New York, p 383-398

Stainton MP, Capel MJ, Armstrong FA (1974) The chemical analysis of freshwater. Miscellaneous Special Publication 25, Department of the Environment, Freshwater Institute, Research and Development Directorate, Winnipeg

Sterrer W (1986) Marine fauna and flora of Bermuda. John Wiley and Sons, New York

Strickland JDH, Parsons TR (1972) A practical handbook of seawater analysis. Bull Fish Res Bd Can 167

Strong DR (1992) Are trophic cascades all wet? Differentiation and donor-control in speciose systems. Ecology 73 : $747-754$

Thayer GW, Bjorndal KA, Ogden JC, Williams SL, Zieman JC (1984) Role of larger herbivores in seagrass communities. Estuaries 7:351-376

Tomasko DA, Dawes CJ (1989) Evidence for physiological integration between shaded and unshaded short shoots of Thalassia testudinum. Mar Ecol Prog Ser 54:299-305

Tomasko DA, Lapointe BE (1991) Productivity and biomass of Thalassia testudinum as related to water column nutrient availability and epiphyte levels: field observations and experimental studies. Mar Ecol Prog Ser 75:9-17

Twilley RR, Kemp WM, Staver KW, Stevenson JC, Boynton WR (1985) Nutrient enrichment of estuarine submerged vascular plant communities. I. Algal growth and effects on production of plants and associated communities. Mar Ecol Prog Ser 23:179-191

Vadas RL, Fenchel T, Ogden JC (1982) Ecological studies on the sea urchin, Lytechinus variegatus, and the algalseagrass communities of the Miskito Cays, Nicaragua Aquat Bot 14:109-125

Valentine JF, Heck KL Jr (1991) The role of sea urchin grazing in regulating subtropical seagrass meadows: evidence from field manipulations in the northern Gulf of Mexico J exp mar Biol Ecol 154:215-230

Valiela I, Teal JM, Cogswell C, Hartman J, Allen S, Van Etten R, Goehringer D (1985) Some long-term consequences of sewage contamination in salt marsh ecosystems. In: Godfrey PJ, Kaynor ER, Pelczarski S, Benforado J (eds) Ecological considerations in wetlands treatment of municipal wastewaters. Van Nostrand Reinhold, New York, p $301-316$

Valiela I, Costa J, Foreman K, Teal JM, Howes B, Aubrey B (1990) Transport of groundwater-borne nutrients from watersheds and their effects on coastal waters. Biogeochemistry 10:177-197

Valiela I, Foreman K, LaMonagne M, Hersh D, Costa J, Peckol P, DeMeo-Anerson B, D'Avanzo C, Babione M, Sham CH, Brawley J, Lajtha K (1992) Couplings of watersheds and coastal waters: sources and consequences of nutrient enrichment in Waquoit Bay, Massachusetts. 
Estuaries 15:443-457

van Montfrans JJ, Wetzel RL, Orth RJ (1984) Epiphyte-grazer relationships in seagrass meadows: consequences for seagrass growth and production. Estuaries 7:289-309

van Vierssen W. Prins TC (1985) On the relationship between growth of algae and aquatic macrophytes in brackish water. Aquat Bot 21:165-179

Vince SW, Valiela I, Teal JM (1981) An experimental study of the structure of herbivorous insect communities in a salt marsh. Ecology 62:1662-1678

Virnstein RW, Carbonara PA (1985) Seasonal abundance and distribution of drift algae and seagrass in the mid-Indian River Lagoon, Florida. Aquat Bot 23:67-82

von Bodungen $B_{1}$ Jickells TD, Smith SR, Ward JAD, Hillier GB (1982) The Bermuda marine environment, Vol III, The final report of the Bermuda Inshore Waters Investigations

This article was submitted to the editor
1975-1980. Bermuda Biological Station Special Publication No 18

Williams SL (1990) Experimental studies of Caribbean seagrass bed development. Ecol Monogr 60:449-469

Williams SL, Ruckelshaus MH (1993) Effects of nitrogen availability and herbivory on eelgrass (Zostera marina) and epiphytes. Ecology 74:904-918

Wooton JT (1991) Direct and indirect effects of nutrients on intertidal community structure: variable consequences of seabird guano. J exp mar Biol Ecol 151:139-153

Zieman JC (1974) Methods for the study of the growth and production of turtle grass, Thalassia testudinum Konig. Aquaculture 4:139-143

Zieman JC, Iverson RL, Ogden JC (1984) Herbivory effects on Thalassia testudinum leaf growth and nitrogen content. Mar Ecol Prog Ser 15:151-158

Manuscript first received: April 22, 1994

Revised version accepted: February 14, 1995 